\title{
Blog-Assisted Language Learning in The Writing Class: Opportunities or Threats?
}

\author{
$1^{\text {st }}$ Teguh Sulistyo ${ }^{1}, 2^{\text {nd }}$ Dwi Fita Heriyawati ${ }^{1}$ \\ \{sulistyoteguh@unikama.ac.id ${ }^{1}$,heriyawatifita@gmail.com ${ }^{1}$ \} \\ Universitas Kanjuruhan Malang, Malang, Indonesia ${ }^{1}$
}

\begin{abstract}
Blog-Assisted language Learn-ing (BALL) is an often-updated website which displays entries containing texts, graphics, and topic-related hyperlinks usually in a reverse chronological order which can be commented by visitors. This paper aims at examining the students' perceptions towards the use of BALL in the writing class. A total of 30 students majoring in English Education Department of a private university took part in this study. The data were obtained from an 8- item open-ended questionnaire which was followed by an in-depth interview. The students expressed their perceptions towards BALL after being treated using BALL in one consecutive semester consisting of 16 weeks. The results showed that in majority the students have positive attitudes towards BALL and they developed their integrative and instrumental motivation during the treatment
\end{abstract}

Keywords: blogs; perceptions; integrative motivation; instrumental motivation.

\section{Introduction}

The rapid development of Information and Communication Technology (ICT) truly corresponds positively to the teaching - learning process of English as a second or foreign language. Ref. [1] claims that the use of ICT in the classrooms has rapidly developed as students have become increasingly tech-savvy. Ref. [2] mentions that today and more than ever before, there is a tendency to practice more writing on computers and the like: likewise, more people have adopted the habit of on-screen reading. According to Ref. [3], advances in ICT have advantageous potentials in second language writing. Therefore, it stands to logic that ignoring the role of ICT in the writing classroom is irrational. In short, ICT should be integrated in teaching-learning process, including EFL writing class settings.

ICT can be widely used in a variety of ways to facilitate students improve their writing skills. Ref. [4], for instance, applied Blogs and Ning in her EFL writing classes. Ref. [5] also suggests that teachers apply search engines in writing classes such as Google, Bing, Dogpile, or WebCrawler. In addition, Ref. [6] mentions that ICT use, such as Blog - Assisted Language Learning (BALL) seems to be well integrated into writing classes, serving as a tool in creating an interactive atmosphere.

BALL as one of ICT modes has been also used widely in different settings of teaching learning process. BALL is an often-updated website which displays entries containing texts, graphics, and topic-related hyperlinks usually in a reverse chronological order which can be commented by visitors [7]. Ref. [8] specifies BALL as a web-based space for writing where all the writing and editing of information is managed through a web browser and is 
immediately and publically available on the internet. In addition, computer technologies including weblogs seem to be well integrated into writing classes, serving as an aid in creating an interactive atmosphere in which students can keep their motivation high [6], and by publishing the blog online students have the opportunity of writing for readers or classmates [8]. Furthermore, BALL offers learners opportunities to conduct the pre-writing, drafting, peer review, and revising steps of the writing process. In short, Ball is a beneficial tool to improve learners' writing proficiency when it is integrated with process writing approach [4].

Several studies investigating the roles of BALL in the writing classes have been conducted by a number of researchers. Ref. [3] found that second language writing students are enthusiastic about BALL in principle, but are not motivated to engage voluntarily in second language blogging activities in practice. Ref. [8] revealed that BALL proves to be an effective tool for students to improve English writing, but he suggests that educators be aware of students' perceptions and reaction for the use of blogs as a pedagogical tool for EFL students. Ref. [7], on the other hand, revealed that the interaction between bloggers was limited; thus, the study indicates the restricted use of BALL as a tool promoting collaboration in the foreign language classroom.

The findings seem provide inconsistent results suggesting further research focusing on the students' perceptions towards the implementation of BALL in the writing class. Thus the research questions are formulated as follows: (1) What are the students' perceptions towards the use of BALL in the writing class? (2) Why did they accept (or reject) BALL?

\section{Methods}

This study aims at investigating the students' perceptions towards BALL in the writing class after they were treated using BALL during one consecutive semester consisting of 16 weeks in which there were 2 credits (100 minutes) in a week. A total of 30 students majoring in English Education Department of a private university took part in this study. The data were obtained from an 8- item open-ended questionnaire which was followed by an in-depth interview (see Appendix 1). All respondents answered the items in the questionnaire, then the researcher audio recorded 10 students in an in-depth interview related to the items in the questionnaire in order to get more data related to the students' perceptions towards BALL in the writing class.

\section{Findings and Discussion}

The findings demonstrate that the majority of the students (25 students) have positive perceptions towards the intervention and the rest 5 students have negative perceptions. The findings are in harmony with the results of Ref. [9] research which found that the students have positive perceptions towards blog since it reduces their writing apprehension and improves their writing quality. Ref. [2] found BALL has potentials to stimulate discussion and provide feedback, so students are encouraged to make more effort to improve their writings. Then Ref. [10] found that students have overall positive attitudes towards BALL. Also, Ref. [3] and Ref. [11] found that blog increases students' motivation and self- efficacy. A statement of a student in the in-depth study reveals the importance of motivation in L2 learning: 
"I like to share my texts in the class blog since I know I will get feedback from my friends and lecturer to improve the quality of my texts. It is motivating to share my texts in the blog because I believe in my own writing quality".

The statement of the respondent is in line with the results of a study by Ref. [12] revealing that BALL motivates the students to use English because of interaction with classmates and teacher. Motivation in L2 acquisition is very important in influencing the outcomes of learning. Ref. [13] states that motivation has a very crucial impact in learning English as ESL or EFL. She further explains that there are three main keys of motivation: (1) positive attitudes towards L2 community, (2) the enjoyment of learning, and (3) external pressures.

Positive attitudes towards L2 community can be a reflection of the intervention of the BALL in the writing class. [14] found that students have positive attitudes to learn English in two terms: Integrative and instrumental motivation. Integrative motivation reflects the learners' willingness to be like a representative member of L2 community. On the contrary, instrumental motivation refers to the need to achieve social recognition or economic advantages through mastering an L2, such as high salary, power, or career.

Integrative motivation may be reflected in this research as students' effort to be able to produce high quality texts, so they work hard in accomplishing their writing tasks. Another respondent said that she did her best in writing her essay because she knew that her texts would be read by his classmates and lecturer. Her opinions seem in line with Ref. [15] which avows that students have positive perceptions in applying blog and it fosters self-regulation and autonomous learning in the target language. Her motivation resulted on the quality of her texts because, according to the findings of Ref. [16], motivation increases students' L2 competence and performance.

In contrast, instrumental motivation can be detected from another respondent's comment who said that she needs writing ability because she has to write her thesis and later on probably she will be a teacher after graduation. Thus BALL motivates them to work harder in writing activities. Ref. [2] found that blog encourages students to work hard as indicated by their hard efforts to improve their writing quality. Also, Ref. [15] revealed that students have positive perceptions in applying blog and it fosters self-regulation and autonomous learning in the target language.

Meanwhile, there are five respondents rejecting BALL for two different reasons: lack of self-efficacy in writing and lack of technology savvy. Self-efficacy, in L2 context, is defined as beliefs in students' capabilities to accomplish a certain task [17], and technology savvy refers to the students' capabilities to apply technology in L2 learning. The students rejecting BALL had different performances in writing: 2 students belonged to high achievers, 2 students were average achievers, and the rest, 1 student, was a low achiever. Thus, there was no guaranty that average - high achievers always accept BALL or low achievers tend to reject BALL.

Self-efficacy in L2 in general motivates students to work in comfort. Somehow, a study by Ref. [18] exploring the relationship between academic self-efficacy and language learning motivation found that there is a low level of negative correlation between the two variables. In this present research a student does not feel comfortable to share her product in the blog since she is not really sure with the quality of her essay. She states as follows:

"I am not confident enough to publish my essay in the blog because I am afraid that it has a lot of errors. Thus I prefer pen and paper - based activities".

The statement above implies that the student is not happy posting her essay because it will be read by online readers due to her capacity in writing an essay. With pen and paper - based activities, it is only the lecturer who will read her product. It is in line with the findings of a study by Ref. [17] stating that students' perceptions about language learning are affected by 
their English self-efficacy. That is why, it is suggested that lecturers encourage their students to have more self-efficacy in language learning, so the outcomes of teaching learning process will be achieved. It is also supported by Ref. [19] stating that self-efficacy is a valid predictor of students' performance in different language skills and tasks. Thus the higher self-efficacy a student has the better achievement he/she gets.

\section{Conclusions}

The implementation of BALL in integration with process writing approach make students in majority have positive perceptions towards BALL. It increases students' motivation and self-efficacy since they can share their products in the blog and get real online audiences in writing activities. Self-efficacy motivates the students to share their products because they have enough confidence with their writing performance. In fact, they have two different kinds of motivation in joining the class blog namely integrative and instrumental motivation. In contrast, a number of students (minority) rejected BALL because of two reasons: lack of selfefficacy in writing and lack of technology savvy. Thus the students with sufficient self-efficacy and technology savvy have a tendency to enjoy BALL in writing classes, but those who lack of the two aspects tend to avoid BALL.

Eventhough in majority students agree with BALL, the teacher should consider the students' fear of lack of self-efficacy and technology savvy when he/she introduces and implements BALL. He/she teachers also needs to encourage students to be more familiar with ICT, especially BALL, and to train students how to work with it since it has been widely applied in the teaching and learning of English, including writing classes.

Acknowledgment. This paper in conjuction with The 1st Annual International Conference on Language, Literature and Media (AICoLLiM 2018) in Malang, East Java.

\section{References}

[1] A.M. Lavin, L. Korte \& T.L. Davies "The impact of classroom technology on student behaviour". Journal of Technology Research, 2012. 1-13.

[2] T. Boudjadar. "ICT in the writing classroom: the pros and the cons". International Journal of Applied Linguistics \& English Literature. vol. 4 no.1 2015, pp. 8-13.

[3] M.H. Lin, N. Groom \& C.Y. Lin "Blog-assisted language learning in the ESL writing classroom: a phenomenological analysis." Educational Technology \& Society, vol. 16 no.3 2013, pp.130-139.

[4] I.V Boas " process writing and the internet: blogs and ning networks in the classroom" English Teaching Forum vol.2, 2011, pp.26-33.

[5] K.J. Hyatt, J. Gunnel, C. Roberts \& H. Smith Integrating Technology throughout Writing Process. https://www.hetl.org/2013/07/page/2/ 2013.

[6] A. Acar, J. Geluso \& T Shiki "How can search engines improve your writing. CALL-EJ, vol. 12 no.1, 2012, pp. 1-10.

[7] D. Domalewska "Technology-supported classroom for collaborative learning: blogging in the foreign language classroom." International Journal of Education and Development using Information and Communication Technology (IJEDICT), 10 (4), 2014, pp.21-30.

[8] Zhang, D. "The application of blog in English writing”. Journal of Cambridge Studies,vol. 4 no.1, 2009, pp.64-71. 
[9] A.I. Challob, N.A. Bakar \& H. Latif "Collaborative blended learning writing environment: effect on EFL students' writing apprehension and writing performance" English Language Teaching, vol. 9 no.6, 2016, pp. 229-241.

[10] G. Ahluwalia, D.A. Gupta \& D. Aggarwal "The use of blogs in English language learning: a study of student perceptions" Profile, vol. 13 no.2, 2011, pp. 29-41.

[11] H.Zhang, W. Song, S. Shen \& R. Huang "The effects of blog-mediated peer feedback on learners' motivation, collaboration, and course satisfaction in a second language writing course". Australasian Journal of Educational Technology, vol. 30 no.6, 2014, pp.670-685.

[12] K. Pinkman "Using blogs in the foreign language classroom: encouraging learner independence" The JALT CALL Journal, vol. 1 no.1, 2005, pp.12-24.

[13] M. Alizadeh "The Impact of Motivation on English Language Learning". International Journal of Research in English Education, vol. 1 no.1 2016, pp.11-15.

[14] S.D. Ghahzani \& K. Khajekpour "Attitudes and motivation in learning English as second language in high school students". Procedia Social and Behavioral Sciences, vol.15, 2011, pp.12091213.

[15] M. Foroutan, N. Noordin \& M.S.G Hamzah "Weblog promotes ESL learners' writing autonomy". Journal of Language Teaching and Research, vol. 4 no.5, 2013, pp.994-1002.

[16] N. Babaee "Motivation in learning English as a second language: a literature review" Canadian Journal for New Scholars in Education, vol. 4 no.1, 2012, pp.1-7.

[17] G. Genc, E. Kulusakli \& S. Aydin "Exploring prospective EFL learners' perceived selfefficacy and beliefs on English language learning". Australian Journal of Education, vol.41 no. 2, 2016, pp.53-68.

[18] C.Y. Ersanly "The relationship between students' academic self-efficacy and language learning motivation: A study of 8th graders. Procedia Social and behavioral sciences, vol. 199, 2015, pp.472-478.

[19] S. Raoofi, B.H. Tan \& S.H. Chan "Self-efficacy in second/foreign language learning contexts". English Language Teaching, vol. 5 no.11, 2012, pp. 60-73.

\section{Appendix A. Open Ended-questionnaire about Students' Perception towards BALL}

1. What do you think of Writing class?

2. What do you know about the importance of writing skills for your future

3. What do you feel if your products are read by your classmates?

4. What do you feel if your products are read by your lecturer?

5. What do you feel if you get feedback from your classmates and lecturer in the class blog?

6. What do you feel if your products are published in the class blog?

7. What is your opinion related to the implementation of BALL in writing class?

8. Is there anything else you want to say or comment about what we have been doing in the Writing class? 